\title{
PENGEMBANGAN SEKTOR EKONOMI DAN PENGENTASAN KEMISKINAN DI KALIMANTAN BARAT
}

\author{
Murohman $^{1}$, Manuntun Parulian Hutagaol ${ }^{2}$, Alla Asmara ${ }^{2}$ \\ ${ }^{1}$ Badan Pusat Statistik Provinsi Kalimantan Barat \\ ${ }^{2}$ Staff Pengajar FEM IPB
}

\begin{abstract}
Kalimantan Barat is a province which has the highest poverty rates among other provinces in Kalimantan. Sector's output growth of the economy affects the redistribution of income and poverty reduction. Increased economic sector output reduce poverty through the distribution of income. Sector development policy needed to boost the economy and poverty alleviation. This study aimed to analyze the relationship between sector's output growth of the economy and poverty reduction using Input-Output Miyazawa and decomposition of FGT (Foster-Greer-Thorbecke) poverty index. Agricultural sector has an important role in output growth, employment, and household income distribution.The decomposition method showes that direct effect of growth in manufacture alleviates poverty among poor households, and total effect of growth in agricultural sectors(food crops and estate crops) alleviates poverty among poor households in Kalimantan Barat. The main policy implication is agricultural industrialization and human capital of the poor needs to be enhanced by education and training if they are not to be sealed off the industrialization process.
\end{abstract}

Keywords: I-O Miyazawa, Poverty, Multiplier Analysis

\section{PENDAHULUAN}

Tujuan akhir dari setiap negara melaksanakan pembangunan adalah menuju pada peningkatan kemakmuran masyarakat secara luas dan pemerataan kesejahteraan. Kenaikan kesejahteraan masyarakat suatu negara salah satunya dicerminkan melalui pertumbuhan ekonomi dan pendapatan perkapita masyarakat yang tinggi. Pendapatan perkapita merupakan indikator yang sering digunakan sebagai tolok ukur kinerja perekonomian secara keseluruhan walaupun tidak menggambarkan kesejahteraan masyarakat secara utuh. Faktor penting yang diabaikan dalam mengukur kesejahteraan dengan menggunakan pendapatan perkapita adalah distribusi pendapatan, yaitu bagaimana keseluruhan pendapatan yang diperoleh didistribusikan kepada masyarakat. Tidak meratanya distribusi pendapatan memicu terjadinya ketimpangan pendapatan yang merupakan awal munculnya masalah kemiskinan. Kemiskinan merupakan masalah pembangunan yang dihadapi oleh semua negara termasuk di Indonesia. Pengentasan kemiskinan menjadi tujuan akhir dari sebuah proses pembangunan sebagai bentuk pemerataan kesejahteraan bagi masyarakat.

Ketimpangan pendapatan atau perbedaan pendapatan yang terjadi antara penduduk miskin dan non miskin dapat dikurangi secara otomatis melalui mekanisme penetesan ke bawah (trickle down effect) hasil pembangunan. Mekanisme ini akan memberikan keseimbangan baru dalam pemerataan pendapatan yang diperoleh dalam perekonomian. Peningkatan pendapatan 
dalam perekonomian dapat diwujudkan melalui peningkatan pertumbuhan ekonomi, sedangkan pemerataan pendapatan terwujud jika pertumbuhan ekonomi didistribusikan secara merata kepada pemilik faktor produksi. Pengentasan kemiskinan dilakukan bukan hanya menjaga pertumbuhan ekonomi tetap tinggi, namun juga komposisi dari pertumbuhan ekonomi sehingga memberikan manfaat dalam mengurangi jumlah penduduk miskin (pro poor growth).

Kalimantan Barat merupakan salah satu provinsi di Indonesia yang mempunyai letak strategis. Wilayah daratnya berbatasan langsung dengan negara Malaysia yang sudah memiliki pintu perbatasan antarnegara yang resmi. Sedangkan wilayah lautnya dilintasi oleh pelayaran perdagangan internasional. Kondisi demikian membuat Kalimantan Barat memiliki keunggulan secara geografis, namun di sisi lain kondisi perekonomian dan kesejahteraan masyarakat masih tertinggal dengan daerah lain. Tingkat kemiskinan di Kalimantan Barat sebesar $8,07 \%$ dengan jumlah penduduk miskin sebesar 359,5 ribu jiwa pada tahun 2012 (BPS 2013). Kemiskinan di Kalimantan Barat masih cukup tinggi walaupun bukan yang terburuk. Tingkat kemiskinan di Kalimantan Barat lebih rendah dari rata-rata nasional sebesar $11,81 \%$, namun demikian tingkat kemiskinan dan jumlah absolut penduduk miskin di Kalimantan Barat masih cukup tinggi dan lebih besar jika dibandingkan dengan provinsi lain di Kalimantan. Selain masih tingginya jumlah penduduk miskin di Kalimantan Barat penurunan tingkat kemiskinan mengalami perlambatan dan mempunyai tendensi mengalami peningkatan (BPS, 2013).
Kemiskinan dapat ditimbulkan oleh kebijakan yang bias. Jumlah penduduk miskin di daerah pedesaan masih cukup banyak dibandingkan dengan daerah perkotaan. Pada tahun 2012 persentase penduduk miskin yang tinggal di pedesaan sebesar $9,08 \%$ atau sebanyak 282 ribu jiwa penduduk miskin berada di pedesaan, sedangkan persentase penduduk miskin yang tinggal di perkotaan sebesar $5,74 \%$ atau sebanyak 77 ribu jiwa penduduk miskin berada di perkotaan. Selama periode 2007-2012 kemiskinan di perkotaan mengalami penurunan yang lebih cepat daripada di pedesaan. Tingginya tingkat kemiskinan di pedesaan disebabkan kebijakan pembangunan bias perkotaan dan sektor industri, sementara alokasi anggaran sektor pertanian menurun drastis (Sajogyo, 2002). Kebijakan ini dinilai keliru karena memarginalkan hak masyarakat dan menumbuhkan kantongkantong kemakmuran masyarakat perkotaan di tengah kemiskinan masyarakat pedesaan (Sudaryanto dan Rusastra 2006).

Kebijakan yang bias juga terjadi pada pengembangan sektor ekonomi. Penduduk miskin yang bekerja pada sektor pertanian masih cukup tinggi. Selama tahun 2009-2012 persentase penduduk miskin terbesar berada pada sektor pertanian dengan rata-rata sebesar $6,95 \%$ diikuti oleh sektor konstruksi dan industri masing-masing sebesar 0,59\% dan $0,35 \%$. Salah satu karakteristik penduduk miskin secara spesifik sebagian besar tinggal di pedesaan dengan mata pencaharian dominan berusaha sendiri di sektor pertanian (Pasaribu, 2006) dan pengembangan sektor pertanian menjadi sangat penting dalam upaya menurunkan tingkat kemiskinan (Yudhoyono (2004), Datt dan Ravallion 1996), serta Matsuyama (1992)). 
Tabel 1 Tingkat kemiskinan menurut sektor ekonomi di Kalimantan Barat tahun 20092012 (persen)

\begin{tabular}{lcccrr}
\hline \multicolumn{1}{c}{ Sektor ekonomi } & \multicolumn{2}{l}{2009} & \multicolumn{2}{l}{2010} & \multicolumn{2}{l}{2011} & 2012 & Rata-rata \\
\hline Pertanian & 7.58 & 7.61 & 6,72 & 5,90 & 6,95 \\
Pertambangan & 0,34 & 0,32 & 0,15 & 0,33 & 0,29 \\
Industri & 0,23 & 0,60 & 0,20 & 0,36 & 0,35 \\
Listrik, Gas, Air Minum & 0,00 & 0,00 & 0,00 & 0,00 & 0,00 \\
Konstruksi & 0,42 & 0,28 & 0,89 & 0,78 & 0,59 \\
Perdagangan & 0,36 & 0,11 & 0,24 & 0,18 & 0,22 \\
Transportasi dan Komunikasi & 0,02 & 0,04 & 0,05 & 0,19 & 0,07 \\
Keuangan dan Jasa & 0,00 & 0,00 & 0,00 & 0,00 & 0,00 \\
Jasa Lainnya & 0,36 & 0,07 & 0,34 & 0,32 & 0,27 \\
\hline Total & 9,30 & 9,02 & 8,60 & 8,07 & 8,75 \\
\hline
\end{tabular}

Kemiskinan besifat multidimensional dan memiliki banyak aspek. Dimensi kemiskinan termanifestasikan dalam bentuk kekurangan gizi, air perumahan yang sehat, perawatan kesehatan yang kurang baik, dan tingkat pendidikan yang rendah (Arsyad, 2010). Kualitas pemenuhan kebutuhan hidup yang rendah tersebut merupakan cerminan dari rendahnya daya beli masyarakat. Daya beli yang rendah berarti tingkat konsumsi penduduk masih dibawah garis kemiskinan yang membedakannya antara golongan penduduk miskin dan tidak miskin. Konsumsi barang dan jasa sangat ditentukan oleh pendapatan yang diperoleh penduduk. Semakin tinggi pendapatan yang diperoleh maka semakin tinggi kesempatan untuk terlepas dari kemiskinan. Rendahnya daya beli yang dialami oleh penduduk miskin karena mereka tidak memiliki pendapatan atau pendapatan yang diperoleh masih rendah. Rumah tangga miskin erat kaitannya dengan pendapatan tenaga kerja, dan pendapatan tenaga kerja tergantung pada struktur umur, tingkat partisipasi angkatan kerja, status pekerjaan, dan tingkat upah (Lipton dan Ravallion, 1993). Partisipasi angkatan kerja dalam menciptakan pendapatan dapat dilihat dari jumlah penduduk yang bekerja, sedangkan penduduk yang tidak mempunyai pendapatan terlihat dari tingkat pengangguran dalam angkatan kerja. Pengangguran merupakan salah satu indikasi kemiskinan dalam rumah tangga.

Upaya peningkatan pendapatan dalam rumah tangga dapat dilakukan melalui peningkatan balas jasa faktor baik dalam bentuk upah maupun surplus usaha dalam rumah tangga. Peningkatan upah dan surplus usaha dalam rumah tangga dapat dilakukan melalui peningkatan produksi. Peningkatan produksi akan meningkatkan balas jasa faktor yang merupakan nilai tambah dalam produksi. Peningkatan nilai tambah berarti terjadi pertumbuhan ekonomi. Pengembangan sektor ekonomi diperlukan sebagai upaya peningkatan pendapatan yang akan diperoleh rumah tangga.

Sudah menjadi konsensus bersama bahwa pertumbuhan menjadi syarat yang diperlukan (necesarry condition) untuk menurunkan kemiskinan, namun belum menjadi syarat kecukupan (sufficient condition). Pertumbuhan ekonomi yang berdiri sendiri ibarat pisau yang akan berkurang ketajaman atau manfaatnya bagi pengentasan kemiskinan (Kakwani et al., 2004). Pengentasan kemiskinan akan mampu berjalan lebih efektif jika pertumbuhan yang dihasilkan diimbangi dengan kebijakan redistribusi pen- 
dapatan, aset, kekayaan serta ketrampilan yang akan membawa pada kondisi distribusi yang lebih merata (Bourguignon, 2004). Pertumbuhan ekonomi yang memberikan dampak terhadap kemiskinan dipengaruhi oleh komposisi pertumbuhan sektoral. Per- tumbuhan pada sektor ekonomi dimana penduduk miskin terkonsentrasi akan memberikan dampak pengurangan kemiskinan yang lebih besar daripada pertumbuhan sektor ekonomi lainnya (Ames et al., 2001).

Tabel 2 Pertumbuhan produk domestik regional bruto (PDRB) menurut sektor ekonomi tahun 2009-2012 (persen)

\begin{tabular}{lrrrrr}
\hline \multicolumn{1}{c}{ Sektor ekonomi } & 2009 & 2010 & 2011 & 2012 & Rata-rata \\
\hline Pertanian & 3,99 & 4,24 & 4,56 & 4,30 & 4,27 \\
Pertambangan dan Penggalian & 9,03 & 8,96 & 7,07 & 5,15 & 7,55 \\
Industri Pengolahan & 0,80 & 2,23 & 2,56 & 3,10 & 2,17 \\
Listrik, Gas, dan Air & 4,36 & 7,17 & 3,91 & 4,62 & 5,01 \\
Bangunan & 7,58 & 8,23 & 9,44 & 9,78 & 8,76 \\
Perdagangan, hotel, dan & & & & & 5,64 \\
Restoran & 3,90 & 5,57 & 6,49 & 6,60 & 10,19 \\
Transportasi dan Komunikasi & 13,29 & 10,21 & 10,69 & 6,56 & 6,10 \\
Keuangan, Persewaan, dan Jasa & & & & & 6,55 \\
Perusahaan & 7,73 & 3,87 & 6,13 & 6,66 & 5,71 \\
Jasa-jasa & 5,90 & 6,08 & 6,53 & 5,53 & \\
\hline \multicolumn{1}{c}{ Jumlah } & 4,80 & 5,47 & 5,97 & 5,83 & \\
\hline
\end{tabular}

Salah satu indikator penting untuk mengetahui kondisi ekonomi di suatu wilayah dalam periode tertentu adalah data Produk Domestik Regional Bruto (PDRB). PDRB pada dasarnya merupakan jumlah nilai tambah yang dihasilkan oleh seluruh unit produksi dalam suatu wilayah, atau merupakan jumlah nilai barang dan jasa akhir yang dihasilkan oleh seluruh unit ekonomi. Beralihnya struktur lapangan usaha sebagian masyarakat Kalimantan Barat dari sektor pertanian ke sektor ekonomi lainnya dapat terlihat dari besarnya peranan masing-masing sektor ini terhadap pembentukan PDRB Kalimantan Barat. Pada tahun 2012 sumbangan terbesar dihasilkan oleh sektor pertanian, kemudian sektor perdagangan, hotel dan restoran, dan sektor industri pengolahan (BPS, 2013 $3^{\mathrm{b}}$ ). Selama lima tahun terakhir peranan sektor pertanian dalam pembentukan PDRB mengalami penurunan. Pergeseran perekonomian dari perekonomian tradisional menuju modern terjadi dengan penurunan kontribusi sektor pertanian secara bertahap dan peningkatan kontribusi sektor perdagangan dan jasa-jasa tanpa melewati tahap industrialisasi. Sektor industri pengolahan yang diharapkan dapat memberikan nilai tambah yang lebih tinggi terhadap produk primer di Kalimantan Barat kontribusinya justru secara bertahap mengalami penurunan, hal ini menunjukkan proses deindustrialisasi yang sedang terjadi di Kalimantan Barat. Penurunan kontribusi sektor industri pengolahan di Kalimantan Barat terjadi pada subsektor industri barang dari kayu dan hasil hutan lainnya yang mengalami penurunan produksi sebagai akibat penurunan produksi hasil hutan sebagai sumber bahan baku utama industri.

Berdasarkan penghitungan PDRB atas dasar harga konstan 2000, laju pertumbuhan ekonomi Kalimantan Barat tahun 2012 sebesar 5,83 persen dan 
mengalami pelambatan jika dibandingkan pertumbuhan pada tahun 2011 yang sebesar 5,97\%. Seluruh sektor ekonomi pada tahun 2012 mengalami pertumbuhan yang positif. Pertumbuhan tertinggi secara berturut-turut dicapai oleh sektor bangunan sebesar 9,78\%, jasa-jasa sebesar 7,71\%, dan keuangan dan jasa perusahaan sebesar $6,66 \%$ sedangkan pertumbuhan terendah dicapai oleh sektor industri pengolahan sebesar 3,10\%. Selama periode 20082012 pertumbuhan ekonomi Kalimantan Barat berfluktuasi. Pertumbuhan ekonomi terendah terjadi pada tahun 2009 yaitu sebesar $4,80 \%$ dan tertinggi pada tahun 2011 sebesar 5,97\%. Perlambatan pertumbuhan ekonomi yang terjadi pada tahun 2009 terjadi didominasi oleh penurunan pertumbuhan sektor pertanian, industri, dan perdagangan.

Pertumbuhan ekonomi dapat terjadi jika terdapat peningkatan permintaan agregat terhadap produksi barang dan jasa. Menurut Nasoetion (1993) kemiskinan dalam sudut pandang ekonomi merupakan cermin dari rendahnya permintaan agregat (agregat demand). Permintaan agregat yang rendah akan mengurangi insentif untuk mengembangkan produksi dan pendapatan tenaga kerja sebagai balas jasa faktor produksi. Penurunan kemiskinan terjadi jika terdapat pertumbuhan ekonomi, namun demikian besarnya penurunan kemiskinan ditentukan oleh komposisi pertumbuhan sektor ekonomi dimana penduduk miskin terbesar berada (Ravallion dan Datt, 2002). Pertumbuhan ekonomi sektoral ditentukan oleh komposisi sektoral dari permintaan agregat.

Struktur ekonomi dan pola pertumbuhan sektor ekonomi menjadi tantangan bagi pemerintah untuk menentukan kebijakan makroekonomi (sosial dan sektoral) yang mendorong pengurangan kemiskinan (Dewbre et al., 2011). Komposisi dan pertumbuhan output sektor ekonomi merupakan determinan penting dalam pengurangan kemiskinan (Lipton dan Ravallion, 1993), sehingga informasi tentang sektor ekonomi yang efektif dalam meningkatkan perekonomian dan mengurangi kemiskinan penting sebagai dasar pengambilan kebijakan pengembangan sektor ekonomi yang sensitif terhadap pengentasan kemiskinan. Penelitian ini bertujuan untuk menganalisis peranan sektor ekonomi dalam perekonomian dan pengentasan kemiskinan di Kalimantan Barat.

\section{METODE PENELITIAN}

Data yang digunakan dalam penelitian ini berupa data Input Output (I-O) Kalimantan Barat tahun 2010 dan data Survei Sosial Ekonomi Nasional (Susenas). Data yang digunakan bersumber dari Badan Pusat Statistik Provinsi Kalimantan Barat. Alat analisis yang digunakan untuk mencapai tujuan dari penelitian adalah analisis Input Output yang dikembangkan oleh Miyazawa (1968). Input Output yang dikembangkan oleh Miyazawa bukan hanya digunakan untuk menganalisis keterkaitan antar sektor ekonomi (interindustry relationship) tetapi dapat digunakan juga untuk mengetahui dampak sosial terhadap distribusi pada berbagai kelompok pendapatan. Untuk membangun tabel input output model Miyazawa diperlukan data sekunder yang berasal dari Susenas yang digunakan untuk memperoleh rasio dalam pengelompokan pendapatan yang akan digunakan dalam membentuk I-O Miyazawa.

Tabel I-O dan analisisnya pertama kali dikembangkan oleh Wassily Leontief pada akhir dekade 1930-an 
(BPS, 2000). Analisis Input Output merupakan metode yang sistematis mengukur hubungan timbal balik antara berbagai sektor dalam perekonomian yang kompleks, dimana ekonomi yang dimaksud dapat diterapkan pada sistem suatu bangsa, daerah, atau perusahaan (Leontief, 1986). Model I-O merupakan alat analisis ekonomi yang lengkap dan komprehensif. Namun demikian I-O mempunyai keterbatasan sebagai alat analisis. Rasio input output yang tetap atau konstan sepanjang periode analisis merupakan keterbatasan dimana produsen tidak dapat menyesuaikan perubahan-perubahan inputnya atau mengubah proses produksi sehingga analisis yang digunakan hanya memprediksi perekonomian dalam jangka pendek (short run).

Perubahan dari tabel input-output dasar menjadi tabel model Miyazawa dilakukan dengan melakukan pemecahan terhadap komponen permintaan akhir (konsumsi rumah tangga) serta input primer (upah dan gaji serta sebagian surplus usaha yang diterima oleh rumah tangga) menjadi kelompok pendapatan dan pengeluaran menurut wilayah pedesaan dan perkotaan. Komponen permintaan akhir dan input primer tersebut kemudian menjadi variabel endogen dalam sistem I-O.

Penggunaan tabel input output Kalimantan Barat dalam analisis digunakan untuk mengetahui peranan sektor ekonomi terhadap kinerja perekonomian secara keseluruhan. Kinerja perekonomian yang ingin diketahui dalam penelitian ini berupa struktur pembentukan output, tenaga kerja, dan distribusi pendapatan. Analisis dalam tabel input output yang dilakukan dalam penelitan ini yaitu analisis pengganda (pengganda output, tenaga kerja, dan pengganda pendapatan).

Tabel 3 Multiplier Effect menurut tipe dampak

\begin{tabular}{|c|c|c|c|}
\hline Tipe Dampak & Output (Rp) & $\begin{array}{l}\text { Tenaga Kerja } \\
\text { (orang) }\end{array}$ & Pendapatan (Rp) \\
\hline Dampak Awal & 1 & $\mathrm{e}_{\mathrm{i}}$ & $\mathrm{p}_{\mathrm{i}}$ \\
\hline Pengaruh Langsung & $\sum \mathrm{a}_{\mathrm{ij}}$ & $\sum \mathrm{a}_{\mathrm{ij}} \mathrm{e}_{\mathrm{i}}$ & $\sum \mathrm{a}_{\mathrm{ij}} \mathrm{p}_{\mathrm{i}}$ \\
\hline Pengaruh Tidak Langsung & $\sum \mathrm{g}_{\mathrm{ij}}-1-\sum \mathrm{a}_{\mathrm{ij}}$ & $\sum \mathrm{g}_{\mathrm{ij}} \mathrm{e}_{\mathrm{i}}-\sum \mathrm{a}_{\mathrm{ij}} \mathrm{e}_{\mathrm{i}}$ & $\sum \mathrm{g}_{\mathrm{ij}} \mathrm{p}_{\mathrm{i}}-\mathrm{p}_{\mathrm{i}}-\sum \mathrm{a}_{\mathrm{ij}} \mathrm{p}_{\mathrm{i}}$ \\
\hline Dampak Imbasan Konsumsi & $\sum \mathrm{g}^{*_{\mathrm{ij}}}-1-\sum \mathrm{a}_{\mathrm{ij}}$ & $\sum \mathrm{g}^{*_{\mathrm{ij}}} \mathrm{e}_{\mathrm{i}}-\sum \mathrm{a}_{\mathrm{ij}} \mathrm{e}_{\mathrm{i}}$ & $\sum \mathrm{g}^{*}{ }_{\mathrm{ij}} \mathrm{p}_{\mathrm{i}}-\mathrm{p}_{\mathrm{i}}-\sum \mathrm{a}_{\mathrm{ij}} \mathrm{p}_{\mathrm{i}}$ \\
\hline Dampak Total & $\sum \mathrm{g}_{\mathrm{ij}}$ & $\sum \mathrm{g}_{\mathrm{ij}} \mathrm{e}_{\mathrm{i}}$ & $\sum \mathrm{g}_{\mathrm{ij}} \mathrm{p}_{\mathrm{i}}$ \\
\hline Dampak Luberan & $\sum \mathrm{g}_{\mathrm{ij}}-1$ & $\sum g^{*}{ }_{i j} e_{i}-e_{i}$ & $\sum \mathrm{g}_{\mathrm{ij}} \mathrm{p}_{\mathrm{i}}-\mathrm{p}_{\mathrm{i}}$ \\
\hline
\end{tabular}

Sumber : Daryanto dan Hafizrianda (2010)

Keterangan :
$\mathrm{a}_{\mathrm{ij}} \quad=$ koefisien input langsung
$\mathrm{p}_{\mathrm{i}} \quad=$ koefisien pendapatan rumah tangga
$\mathrm{e}_{\mathrm{i}} \quad=$ koefisien tenaga kerja
$\mathrm{g}_{\mathrm{ij}}=$ matrik kebalikan Leontief model terbuka/tipe I [(I-A) $\left.)^{-1}\right]$
$\mathrm{g}{ }_{\mathrm{ij}}=$ matrik kebalikan Leontief model tertutup/Miyazawa $\left[(\mathrm{I}-\mathrm{M})^{-1}\right]$

Analisis angka pengganda (multiplier analysis) digunakan untuk melihat sesuatu yang terjadi pada variabel-variabel endogen yaitu output sektoral sebagai respon dari perubahan yang terjadi pada variabel-variabel eksogen seperti permintaan akhir
(Nazara, 2005). Angka pengganda merupakan ukuran respon terhadap rangsangan perubahan suatu perekonomian (rangsangan berasal dari permintaan akhir) yang dinyatakan dalam hubungan sebab akibat. Jensen dan West (1986) membedakan kategori 
dampak berganda menjadi: (1) dampak awal (initial impact), (2) dampak imbasan kegiatan produksi (production induced impact) yang terdiri atas pengaruh putaran pertama (fist round effect) dan pengaruh putaran kedua atau pengaruh dukungan industri (industrial support effect), (3) dampak imbasan konsumsi (consumption induced effect), serta adanya dampak luberan (flow-on impact).

Analisis pengentasan kemiskinan dalam penelitian ini mengadopsi indeks kemiskinan FGT (Foster-GreerThorbecke) yang didekomposisi sebagai dampak perubahan output sektor ekonomi (Thorbecke and Jung 1994). Indikator kemiskinan yang digunakan dalam penelitian yaitu:

$$
P_{\alpha}(y ; z)=\frac{1}{n} \sum_{i=1}^{q}\left(\frac{z-y_{i}}{z}\right)^{\alpha},(\alpha \geq 0)
$$

dimana $y_{i}$ adalah rata-rata nilai pengeluaran perkapita individu ke-i dalam rumah tangga, $\mathrm{n}$ adalah total populasi, $q$ adalah jumlah populasi penduduk miskin, dan $\mathrm{z}$ adalah garis kemiskinan. Nilai $\alpha=0$, menyatakan headcount index yang merupakan proporsi populasi penduduk yang berada di bawah garis kemiskinan. Nilai $\alpha=1$, menyatakan ukuran poverty gap index atau kesenjangan kemiskinan seluruh populasi miskin terhadap garis kemiskinan. Nilai $\alpha=2$, menyatakan ukuran poverty saverity atau rasio "keparahan" kemiskinan.

Perubahan pada ukuran kemiskinan dapat ditentukan oleh perubahan rata-rata pendapatan perkapita dan perubahan dalam distribusi pendapatan (Kakwani, 1993), yang diformulasikan sebagai berikut:

$$
P_{\alpha i j}=\frac{\partial P_{\alpha i j}}{\partial \bar{y}_{i}} d \bar{y}_{i}+\sum_{k=1}^{l} \frac{\partial P_{\alpha i j}}{\partial \theta_{i j k}} d \theta_{i j k}
$$

dimana $\mathrm{P}_{\text {aij }}$ adalah indeks kemiskinan FGT pada sektor j pada kelompok rumah tangga $\mathrm{i}, \overline{\mathrm{y}}_{\mathrm{i}}$ adalah rata-rata pendapatan kelompok rumah tangga $i$, dan $\Theta_{\mathrm{ijk}}$ menunjukkan parameter distribusi pendapatan. Dengan asumsi perubahan aktifitas produksi output terdistribusi netral, maka:

$$
\frac{d P_{\alpha i j}}{P_{\alpha i j}}=\eta_{\alpha i}\left(\frac{d \bar{y}_{i}}{\bar{y}_{i}}\right)
$$

dimana, $\eta_{\alpha i}$ adalah elastisitas $P_{\alpha \mathrm{ij}}$ sebagai akibat perubahan rata-rata pendapatan perkapita dari kelompok rumah tangga $\mathrm{i}$ sebagai dampak perubahan output sektor ekonomi j. Perubahan indeks kemiskinan sebagai dampak perubahan output sektor ekonomi didekomposisi menurut tipe dampak langsung, tidak langsung, imbasan konsumsi, dan total. Dekomposisi tipe dampak didasarkan pada perhitungan pengganda pendapatan rumah tangga (income multiplier) yang diperoleh dari tabel I-O Miyazawa.

\section{HASIL DAN PEMBAHASAN}

\section{Peranan sektor ekonomi terhadap output perekonomian}

Analisis pengganda output bertujuan untuk melihat dampak dari perubahan permintaan akhir pada suatu sektor ekonomi terhadap perubahan output perekonomian secara keseluruhan. Pengganda output yang dihitung dalam penelitian ini terdiri dari pengganda output tipe I yang terdiri dari dampak awal (initial impact) dan pengaruh dukungan industri (industrial support effect), serta pengganda output Miyazawa yang telah memperhitungkan adanya efek induksi konsumsi (consumption induced effect). Peranan dari masing-masing sektor dalam pembentukan output total perekonomian dapat dilihat pada matrik pengganda output tipe I maupun Miyazawa.

Pengganda output tipe I yang diperlihatkan pada tabel 4 menunjukkan bahwa sektor-sektor ekonomi yang 
mempunyai pengganda output tertinggi dalam perekonomian Kalimantan Barat yaitu sektor hotel dan rumah makan sebesar 2,00; industri sebesar 1,912; kehutanan sebesar 1,876; dan transportasi sebesar 1,713. Nilai pengganda output diatas menunjukkan bahwa jika terjadi peningkatan permintaan akhir terhadap produksi sektor hotel dan rumah makan sebesar Rp. 1 milyar akan berdampak terhadap peningkatan output perekonomian secara keseluruhan sebesar Rp. 2,003 milyar. Hal ini juga berlaku pada perubahan permintaan akhir terhadap produksi sektor-sektor yang lainnya. Sektor yang mempunyai pengganda output tertinggi merupakan pilihan dalam melakukan investasi dimana output perekonomian akan mengalami peningkatan yang lebih cepat jika sektor ini berkembang daripada sektor dengan pengganda output yang lebih rendah.

Tabel 4 Pengganda output sektor ekonomi

\begin{tabular}{|c|c|c|c|c|}
\hline \multirow{2}{*}{ Peringkat } & \multicolumn{2}{|l|}{ Tipe I } & \multicolumn{2}{|l|}{ Miyazawa } \\
\hline & Sektor & Nilai & Sektor & Nilai \\
\hline 1 & Hotel dan rumah makan & 2,0029 & $\begin{array}{l}\text { Pertanian tanaman padi dan } \\
\text { palawija } \\
\text { Jasa kemasyarakatan, }\end{array}$ & 3,2663 \\
\hline 2 & Industri pengolahan & 1,9121 & pemerintahan, dan perorangan & 3,2475 \\
\hline 3 & Kehutanan dan pertanian lainnya & 1,8764 & Industri pengolahan & 3,2311 \\
\hline 4 & Transportasi dan pergudangan & 1,7131 & Konstruksi & 3,1239 \\
\hline 5 & Hortikultura & 1,5803 & Jasa kesehatan & 3,1231 \\
\hline 6 & Peternakan & 1,5461 & Perkebunan & 3,1108 \\
\hline 7 & Jasa pendidikan & 1,5175 & Hotel dan rumah makan & 3,0648 \\
\hline 8 & Jasa kesehatan & 1,4512 & Kehutanan dan pertanian lainnya & 3,0562 \\
\hline 9 & Konstruksi & 1,4489 & Hortikultura & 2,9718 \\
\hline 10 & $\begin{array}{l}\text { Jasa kemasyarakatan, } \\
\text { pemerintahan, dan perorangan } \\
\text { Pertanian tanaman padi dan }\end{array}$ & 1,3504 & Pertambangan dan penggalian & 2,9079 \\
\hline 11 & palawija & 1,3389 & Transportasi dan pergudangan & 2,8499 \\
\hline 12 & Perdagangan & 1,3310 & Peternakan & 2,7290 \\
\hline 13 & Perkebunan & 1,2958 & Jasa pendidikan & 2,4730 \\
\hline 14 & Perikanan & 1,2501 & Perdagangan & 2,4563 \\
\hline 15 & Listrik, air, dan gas & 1,2078 & Informasi dan komunikasi & 2,2523 \\
\hline 16 & $\begin{array}{l}\text { Keuangan, asuransi, dan jasa } \\
\text { perusahaan }\end{array}$ & 1,2057 & $\begin{array}{l}\text { Keuangan, asuransi, dan jasa } \\
\text { perusahaan }\end{array}$ & 2,1954 \\
\hline 17 & Pertambangan dan penggalian & 1,1805 & Perikanan & 2,0181 \\
\hline 18 & Informasi dan komunikasi & 1,1596 & Listrik, air, dan gas & 1,9689 \\
\hline
\end{tabular}

Sumber: I-O Miyazawa 2010 (diolah)

Perubahan pola konsumsi dan pendapatan rumah tangga juga turut berperan dalam menciptakan perubahan output dalam perekonomian di Kalimantan Barat. Hal ini dapat ditunjukkan oleh pengganda output model Miyazawa, dimana sektor-sektor yang mempunyai pengganda output tertinggi yaitu sektor pertanian tanaman padi dan palawija sebesar 3,266, jasa kemasyarakatan dan pemerintahan sebesar 3,247; industri sebesar 3,231; dan transportasi sebesar 3,124. Nilai pengganda output diatas menunjukkan bahwa jika terjadi peningkatan permintaan akhir terhadap produksi pertanian tanaman padi dan palawija sebesar Rp. 1 milyar akan berdampak terhadap peningkatan output perekonomian secara keseluruhan 
sebesar Rp. 3.266 milyar. Hal ini juga berlaku pada perubahan permintaan akhir terhadap produksi sektor-sektor yang lainnya.

\section{Peranan sektor ekonomi terhadap penyerapan tenaga kerja}

Tenaga kerja merupakan salah satu faktor produksi yang memiliki peranan cukup penting dalam suatu proses produksi. Pengeluaran untuk tenaga kerja yang terjadi dalam proses produksi merupakan salah satu komponen input primer, yang antara lain berupa upah dan gaji, tunjangan dan bonus serta termasuk hasil usaha seperti sewa, bunga, keuntungan, baik berupa uang maupun barang. Sesuai dengan asumsi dasar dalam model I-O, maka tenaga kerja memiliki hubungan linear dengan output, sehingga perubahan output di suatu sektor akan berpengaruh terhadap perubahan jumlah tenaga kerja. Perubahan jumlah tenaga kerja yang dibutuhkan dalam proses produksi tergantung dari besarnya koefisien tenaga kerja.

Tabel 5 Pengganda tenaga kerja pada sektor ekonomi (orang/milyar Rp)

\begin{tabular}{|c|c|c|c|c|}
\hline \multirow{2}{*}{$\begin{array}{l}\text { Pering } \\
\text { kat }\end{array}$} & \multicolumn{2}{|l|}{ Tipe I } & \multicolumn{2}{|l|}{ Miyazawa } \\
\hline & Sektor & Nilai & Sektor & Nilai \\
\hline 1 & Pertanian tanaman padi dan palawija & 182 & $\begin{array}{l}\text { Pertanian tanaman padi dan } \\
\text { palawija }\end{array}$ & 229 \\
\hline 2 & Industri pengolahan & 55 & Industri pengolahan & 86 \\
\hline 3 & Peternakan & 39 & Jasa kesehatan & 71 \\
\hline 4 & Hotel dan rumah makan & 36 & Peternakan & 67 \\
\hline 5 & Jasa kesehatan & 33 & Perkebunan & 64 \\
\hline 6 & Hortikultura & 30 & Hortikultura & 63 \\
\hline 7 & Kehutanan dan pertanian lainnya & 27 & $\begin{array}{l}\text { Jasa kemasyarakatan, } \\
\text { pemerintahan, dan perorangan }\end{array}$ & 62 \\
\hline 8 & Perikanan & 24 & Hotel dan rumah makan & 61 \\
\hline 9 & Transportasi dan pergudangan & 24 & Konstruksi & 57 \\
\hline 10 & Jasa pendidikan & 22 & Kehutanan dan pertanian lainnya & 55 \\
\hline 11 & Perkebunan & 20 & Pertambangan dan penggalian & 53 \\
\hline 12 & $\begin{array}{l}\text { Jasa kemasyarakatan, pemerintahan, } \\
\text { dan perorangan }\end{array}$ & 19 & Transportasi dan pergudangan & 50 \\
\hline 13 & Konstruksi & 18 & Jasa pendidikan & 44 \\
\hline 14 & Perdagangan & 17 & Perdagangan & 43 \\
\hline 15 & Pertambangan dan penggalian & 11 & Perikanan & 42 \\
\hline 16 & $\begin{array}{l}\text { Keuangan, asuransi, dan jasa } \\
\text { perusahaan }\end{array}$ & 8 & $\begin{array}{l}\text { Keuangan, asuransi, dan jasa } \\
\text { perusahaan }\end{array}$ & 31 \\
\hline 17 & Listrik, air, dan gas & 7 & Informasi dan komunikasi & 28 \\
\hline 18 & Informasi dan komunikasi & 4 & Listrik, air, dan gas & 24 \\
\hline
\end{tabular}

Sumber: I-O Miyazawa 2010 (diolah)

Berdasarkan penghitungan pengganda tenaga kerja tipe I, diketahui bahwa penyerapan tenaga kerja terbesar terjadi pada sektor pertanian tanaman padi dan palawija. Jika terjadi peningkatan permintaan akhir pada sektor tersebut sebesar Rp. 1 milyar maka akan berdampak terjadinya penyerapan tenaga kerja sebesar 182 orang untuk memproduksi tambahan output sebesar permintaan akhir. Sektor lain yang mempunyai pengganda yang cukup besar yaitu sektor industri pengolahan, peternakan dan hotel dan rumah makan. Jika terjadi peningkatan permintaan akhir sebesar Rp. 1 milyar pada masing-masing sektor, maka akan terjadi penyerapan tenaga kerja masing- 
masing sektor sebesar 55 orang, 39 orang, dan 36 orang. Sedangkan sektorsektor yang mempunyai pengganda tenaga kerja yang rendah terjadi pada sektor keuangan, asuransi, dan jasa perusahaan; listrik, air, dan gas; serta informasi dan komunikasi. Jika terjadi peningkatan permintaan akhir sebesar Rp. 1 milyar pada masing-masing sektor tersebut, maka akan terjadi penyerapan tenaga kerja masing-masing sebesar 8 orang, 7 orang, dan 4 orang.

Pengaruh pola konsumsi dan pendapatan rumah tangga (induced effect) pada model Miyazawa menunjukkan bahwa pengganda tenaga kerja paling besar juga terjadi pada sektor pertanian tanaman padi dan palawija. Pengganda tenaga kerja yang terjadi pada sektor tersebut sebesar 229 orang/milyar rupiah, yang berarti jika terjadi peningkatan permintaan akhir sebesar Rp. 1 milyar terhadap output sektor pertanian padi dan palawija maka sektor tersebut akan membutuhkan tambahan tenaga kerja sebesar 229 orang. Sektor lain yang mempunyai pengganda tenaga kerja yang cukup besar juga terjadi pada sektor-sektor industri pengolahan, jasa kesehatan, dan peternakan. Jika terjadi tambahan permintaan akhir terhadap output sektorsektor tersebut masing-masing sebesar Rp. 1 milyar maka akan terjadi penyerapan tenaga kerja masing-masing sebesar 86 orang, 71 orang, dan 67 orang. Sedangkan sektor-sektor yang mempunyai pengganda tenaga kerja yang rendah juga terjadi pada sektor yang sama dengan pengganda tipe I yaitu sektor keuangan, asuransi, dan jasa perusahaan; informasi dan komunikasi; serta listrik, air, dan gas.

Besarnya nilai pengganda tenaga kerja pada masing-masing sektor dapat menunjukkan teknologi yang digunakan dalam proses produksi. Sektor yang membutuhkan jumlah tenaga kerja yang banyak untuk memproduksi setiap satuan output menunjukkan teknologi yang digunakan pada sektor tersebut bersifat padat tenaga kerja (padat karya), sedangkan sektor yang membutuhkan jumlah tenaga kerja yang sedikit dalam memproduksi output menunjukkan sektor tersebut bersifat padat modal. Kebijakan untuk memajukan perekonomian yang bertujuan memaksimalkan dampak terhadap pengurangan pengangguran (pro job) akan memperoleh hasil yang maksimal jika tambahan permintaan akhir dialokasikan pada sektor-sektor yang yang mempunyai pengganda tenaga kerja yang tinggi serta akan menjadi lebih ideal jika kebijakan tersebut juga dapat mengurangi jumlah penduduk miskin (pro poor).

\section{Peranan sektor ekonomi terhadap distribusi pendapatan rumah tangga}

Analisis pengganda pendapatan dalam penelitian ini bertujuan untuk melihat dampak dari perubahan permintaan akhir pada suatu sektor ekonomi terhadap perubahan pendapatan rumah tangga secara keseluruhan. Pengganda pendapatan yang dihitung dalam penelitian ini terdiri dari pengganda pendapatan tipe I yang terdiri dari dampak awal (initial impact) dan pengaruh dukungan industri (industrial support effect), serta pengganda pendapatan Miyazawa yang telah memperhitungkan adanya efek induksi konsumsi (consumption induced effect). Peranan dari masing-masing sektor dalam perubahan pendapatan rumah tangga secara keseluruhan dapat dilihat pada matrik pengganda pendapatan tipe I maupun Miyazawa.

Berdasarkan penghitungan pengganda pendapatan tipe I, diketahui bahwa sektor pertanian tanaman padi dan palawija memiliki angka pengganda 
tertinggi yaitu sebesar 0,682 ; diikuti oleh sektor jasa kemasyarakatan dan pemerintahan sebesar 0,675 ; perkebunan sebesar 0,642 dan pertambangan dan penggalian sebesar 0,612 . Nilai pengganda pendapatan diatas menunjukkan bahwa jika terjadi peningkatan permintaan akhir terhadap produksi sektor pertanian tanaman padi dan palawija sebesar Rp. 1 milyar maka akan berdampak terhadap peningkatan pendapatan rumah tangga secara keseluruhan sebesar Rp. 0,682 milyar. Hal ini juga berlaku pada perubahan permintaan akhir terhadap produksi sektor-sektor yang lainnya.

Tabel 6 Pengganda pendapatan rumah tangga pada sektor ekonomi

\begin{tabular}{|c|c|c|c|c|c|c|c|}
\hline \multirow{2}{*}{$\begin{array}{l}\text { Sekto } \\
\quad \mathrm{r}\end{array}$} & \multirow[b]{2}{*}{ Uraian } & \multicolumn{3}{|c|}{ Tipe I } & \multicolumn{3}{|c|}{ Miyazawa } \\
\hline & & Desa & Kota & $\begin{array}{l}\text { Desa+Kot } \\
\text { a }\end{array}$ & Desa & Kota & $\begin{array}{c}\text { Desa+Kot } \\
\mathrm{a}\end{array}$ \\
\hline 1 & $\begin{array}{l}\text { Pertanian tanaman padi } \\
\text { dan palawija }\end{array}$ & 0,5715 & 0,1109 & 0,6823 & 0,8820 & 0,3346 & 1,2166 \\
\hline 2 & Hortikultura & 0,3300 & 0,1636 & 0,4936 & 0,5515 & 0,3270 & 0,8784 \\
\hline 3 & Perkebunan & 0,5748 & 0,0676 & 0,6425 & 0,8687 & 0,2776 & 1,1463 \\
\hline 4 & Perikanan & 0,2034 & 0,0688 & 0,2722 & 0,3264 & 0,1584 & 0,4848 \\
\hline 5 & Peternakan & 0,2727 & 0,1468 & 0,4195 & 0,4606 & 0,2858 & 0,7464 \\
\hline 6 & $\begin{array}{l}\text { Kehutanan dan pertanian } \\
\text { lainnya }\end{array}$ & 0,3176 & 0,1004 & 0,4181 & 0,5067 & 0,2381 & 0,7447 \\
\hline 7 & $\begin{array}{l}\text { Pertambangan dan } \\
\text { penggalian }\end{array}$ & 0,5347 & 0,0769 & 0,6117 & 0,8140 & 0,2770 & 1,0910 \\
\hline 8 & Industri pengolahan & 0,3306 & 0,1371 & 0,4677 & 0,5411 & 0,2915 & 0,8326 \\
\hline 9 & Listrik, air, dan gas & 0,0998 & 0,1710 & 0,2708 & 0,2181 & 0,2621 & 0,4802 \\
\hline 10 & Konstruksi & 0,2380 & 0,3576 & 0,5956 & 0,4990 & 0,5576 & 1,0566 \\
\hline 11 & Perdagangan & 0,1662 & 0,2340 & 0,4002 & 0,3418 & 0,3682 & 0,7100 \\
\hline 12 & Hotel dan rumah makan & 0,2167 & 0,1604 & 0,3770 & 0,3844 & 0,2858 & 0,6702 \\
\hline 13 & $\begin{array}{l}\text { Transportasi dan } \\
\text { pergudangan }\end{array}$ & 0,1938 & 0,2102 & 0,4040 & 0,3720 & 0,3453 & 0,7173 \\
\hline 14 & $\begin{array}{l}\text { Informasi dan } \\
\text { komunikasi }\end{array}$ & 0,0308 & 0,3590 & 0,3898 & 0,1968 & 0,4922 & 0,6890 \\
\hline 15 & $\begin{array}{l}\text { Keuangan, asuransi, dan } \\
\text { jasa perusahaan }\end{array}$ & 0,0506 & 0,3023 & 0,3528 & 0,2017 & 0,4224 & 0,6241 \\
\hline 16 & Jasa pendidikan & 0,1560 & 0,1836 & 0,3396 & 0,3056 & 0,2973 & 0,6029 \\
\hline 17 & Jasa kesehatan & 0,1844 & 0,4108 & 0,5951 & 0,4431 & 0,6116 & 1,0547 \\
\hline 18 & $\begin{array}{l}\text { Jasa kemasyarakatan, } \\
\text { pemerintahan, dan } \\
\text { perorangan }\end{array}$ & 0,1956 & 0,4799 & 0,6755 & 0,4887 & 0,7080 & 1,1967 \\
\hline
\end{tabular}

Sumber: I-O Miyazawa, 2010 (diolah)

Pada pengganda pendapatan model Miyazawa dimana terdapat pengaruh pola konsumsi dan pendapatan rumah tangga (induced effect), sektor ekonomi yang mempunyai pengganda tertinggi tidak berbeda pada pengganda pendapatan tipe I. Pengganda pendapatan tertinggi terdapat pada sektor pertanian tanaman padi dan palawija sebesar 1,217; sektor jasa kemasyarakatan dan pemerintahan sebesar 1,197; perkebunan sebesar 1,146, dan pertambangan dan penggalian sebesar 1,091. Nilai pengganda pendapatan diatas menunjukkan bahwa jika terjadi peningkatan permintaan akhir terhadap produksi sektor pertanian tanaman padi dan palawija sebesar Rp. 1 milyar maka akan berdampak terhadap peningkatan pendapatan rumah tangga 
secara keseluruhan sebesar Rp. 1,217 milyar. Hal ini juga berlaku pada perubahan permintaan akhir terhadap produksi sektor-sektor yang lainnya.

Kebijakan yang bertujuan untuk memaksimalkan dampak terhadap peningkatan pendapatan rumah tangga akan memperoleh hasil yang maksimal jika tambahan permintaan akhir dialokasikan pada sektor-sektor yang mempunyai pengganda pendapatan yang tertinggi. Tetapi kebijakan ini belum tentu efektif jika ditujukan dalam rangka memperbaiki distribusi pendapatan dan pengentasan kemiskinan. Peningkatan pendapatan yang diterima oleh rumah tangga secara keseluruhan belum tentu dapat dinikmati secara merata oleh setiap rumah tangga. Kebijakan peningkatan pendapatan dapat menimbulkan dampak terhadap ketimpangan pada distribusi pendapatan jika sektor ekonomi yang dikembangkan memiliki struktur pendapatan yang diterima oleh pekerja tidak merata. Kebijakan yang bertujuan untuk pengentasan kemiskinan akan lebih efektif jika sektor ekonomi yang dikembangkan menjadi penghidupan bagi sebagian besar penduduk miskin di Kalimantan Barat.

\section{Keterkaitan Antar Sektor Ekonomi}

Hubungan atau keterkaitan antar sektor ekonomi dalam perekonomian pada suatu wilayah perlu diketahui dalam kebijakan pengembangan sektor ekonomi. Untuk mengetahui tingkat hubungan atau keterkaitan antar sektor ekonomi dalam perekonomian di Kalimantan Barat digunakan analisis keterkaitan ke depan (forward lingkage) dan keterkaitan ke belakang (backward lingkage) antar sektor ekonomi. Sektorsektor yang mempunyai indeks BL lebih dari 1 merupakan sektor yang strategis dalam memacu pertumbuhan ekonomi, karena secara relatif permintaan akhir terhadap produksi sektor ini akan merangsang pertumbuhan produksi yang lebih besar dari rata-rata. Sedangkan sektor-sektor yang mempunyai indeks FL lebih dari 1 digolongkan sebagai sektor yang strategis, karena secara relatif sektor ini dapat memenuhi permintaan akhir sebanyak diatas kemampuan rata-rata dari sektor lainnya. Analisis tabel Input-Output menunjukkan bahwa sektor ekonomi yang memiliki keterkaitan kebelakang tertinggi adalah sektor hotel dan rumah makan, industri pengolahan, kehutanan, serta transportasi dan pergudangan. Sektor-sektor yang memiliki keterkaitan kebelakang yang tinggi dapat dikategorikan sebagai sektor hilir dalam perekonomian Kalimantan Barat karena memiliki indeks keterkaitan kebelakang yang tinggi dibandingkan sektor yang lainnya. Sektor hilir adalah sektor yang banyak menggunakan input yang berasal dari output sektor-sektor ekonomi lainnya. Sedangkan sektor yang memiliki keterkaitan ke depan tertinggi adalah sektor industri, transportasi dan pergudangan, pertanian padi dan palawija, serta perdagangan. Sektorsektor yang memiliki keterkaitan ke depan yang tinggi dapat dikategorikan sebagai sektor hulu dalam perekonomian. Sektor hulu adalah sektor yang outputnya banyak digunakan sebagai input pada sektor-sektor ekonomi lainnya.

Sektor-sektor yang memiliki keterkaitan ke depan dan ke belakang paling tinggi dikatakan sebagai sektorsektor yang memiliki basis domestik baik dari sisi input maupun output sehingga sektor-sektor semacam ini sangat dibutuhkan dalam pembangunan ekonomi wilayah yang berkelanjutan (Daryanto dan Rusastra, 2010). Sektorsektor strategis yang yang layak dikembangkan dalam meningkatkan pertumbuhan output perekonomian 
adalah sektor industri pengolahan serta transportasi dan pergudangan, dan hortikultura dimana sektor-sektor ini mempunyai pengganda output yang yang cukup besar dan mempunyai potensi dalam mengembangkan sektor-sektor lain yang ada di Kalimantan Barat.

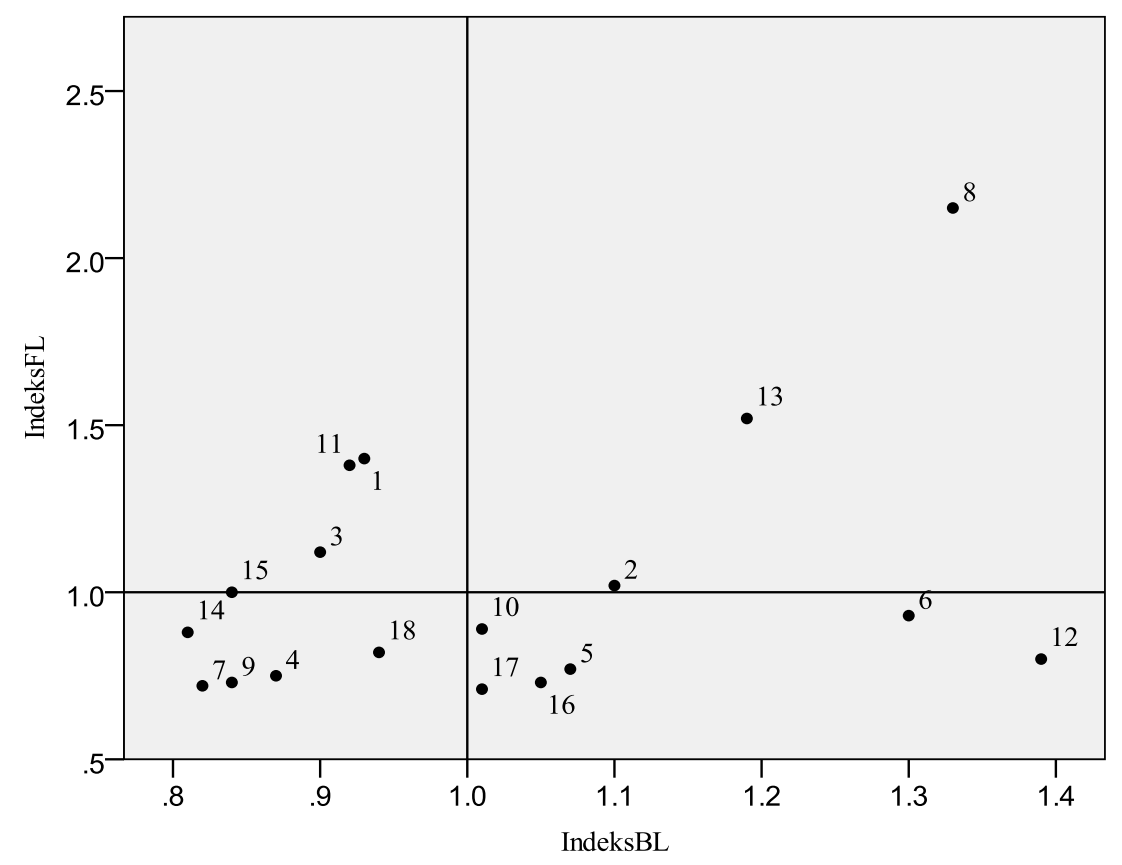

Keterangan:

1. Pertanian padi dan palawija

2. Hortikultura

3. Perkebunan

4. Perikanan

5. Peternakan

6. Kehutanan

7. Pertambangan dan penggalian

8. Industri pengolahan

9. Listrik, gas, dan air

Sumber: I-O Miyazawa 2010 (diolah)

\section{Peranan sektor ekonomi terhadap pengentasan kemiskinan}

Indikator kemiskinan selain tingkat kemiskinan, juga diukur dengan indeks kedalaman kemiskinan (poverty gap) yang merupakan ukuran rata-rata kesenjangan pengeluaran masingmasing penduduk miskin terhadap garis kemiskinan dan indeks keparahan kemiskinan (poverty saverity) yang memberikan gambaran mengenai penyebaran pengeluaran di antara penduduk miskin. Penurunan nilai indeks kedalaman kemiskinan dan keparahan kemiskinan mengindikasikan bahwa rata-rata pengeluaran penduduk miskin cenderung makin mendekati garis kemiskinan dan ketimpangan pengeluaran penduduk miskin juga semakin menyempit sehingga akan menguragi biaya pengentasan kemiskinan yang akan datang. Masalah kemiskinan bukan hanya sekedar jumlah dan persentase penduduk yang miskin saja, terdapat dimensi lain yang perlu mendapat perhatian yaitu tingkat 
kedalaman dan keparahan kemiskinan. Selain menekan jumlah penduduk miskin, kebijakan yang berhubungan dengan kemiskinan diharapkan juga sekaligus mengurangi tingkat kedalaman dan keparahan kemiskinan.

Tabel 7 menunjukkan estimasi perubahan indikator kemiskinan ( $\mathrm{P} 0, \mathrm{P} 1$, dan P2) sebagai akibat perubahan pendapatan dalam rumah tangga. Ratarata pendapatan adalah pendapatan perkapita yang diterima oleh penduduk di Kalimantan Barat selama tahun 2010 sedangkan elastisitas kemiskinan menunjukkan persentase perubahan ukuran kemiskinan sebagai akibat perubahan pendapatan penduduk sebesar $1 \%$ dalam setahun.

Tabel 7 Rata-rata pendapatan penduduk dan elastisitas indeks kemiskinan menurut wilayah di Kalimantan Barat

\begin{tabular}{|c|c|c|c|c|c|c|c|c|}
\hline \multirow[b]{2}{*}{ Wilayah } & \multirow{2}{*}{$\begin{array}{l}\text { Rata-rata } \\
\text { pendapatan } \\
\text { perkapita } \\
\text { (Rp. Juta) } \\
\end{array}$} & \multirow[b]{2}{*}{ Proporsi } & \multicolumn{3}{|c|}{ Elastisitas (\%) } & \multicolumn{3}{|c|}{ Proporsi Kemiskinan } \\
\hline & & & $\mathrm{P} 0$ & $\mathrm{P} 1$ & $\mathrm{P} 2$ & P0 & P1 & P2 \\
\hline Desa & 7,23 & 0,7032 & $-0,3500$ & $-2,0487$ & $-2,8929$ & 0,8661 & 0,8879 & 0,8850 \\
\hline Kota & 14,67 & 0,2968 & $-0,2530$ & $-1,5725$ & $-2,2282$ & 0,1339 & 0,1121 & 0,1150 \\
\hline Desa+Kota & 9,45 & 1,0000 & $-0,3071$ & $-1,8289$ & $-2,5851$ & 1,0000 & 1,0000 & 1,0000 \\
\hline
\end{tabular}

Rata-rata pendapatan perkapita yang diterima penduduk di Kalimantan Barat pada tahun 2010 sebesar Rp. 9,45 juta. Rata-rata pendapatan perkapita yang diterima oleh penduduk di perkotaan dua kali lebih tinggi dari ratarata pendapatan perkapita penduduk di pedesaan. Penduduk yang tinggal di pedesaan dengan proporsi lebih dari $70 \%$ memperolebih pendapatan perkapita yang lebih rendah dari penduduk yang tinggal di perkotaan dimana penduduk di pedesaan menerima pendapatan perkapita sebesar Rp. 7,23 juta lebih rendah dari pendapatan perkapita penduduk di perkotaan sebesar Rp. 14,67 juta. Perubahan ukuran kemiskinan yang ditunjukkan oleh elastisitas terhadap perubahan rata-rata pendapatan perkapita penduduk menunjukkan bahwa perubahan rata-rata pendapatan perkapita mempengaruhi perubahan kemiskinan yang lebih tinggi di pedesaan daripada di perkotaan. Perubahan ratarata pendapatan perkapita yang diterima oleh penduduk di pedesaan sebesar $1 \%$ akan mempengaruhi penurunan $\mathrm{P} 0, \mathrm{P} 1$, dan P2 di pedesaan masing-masing sebesar 0,35\%; 2,05\%; dan 2,89\%. Sedangkan Perubahan rata-rata pendapatan perkapita yang diterima oleh penduduk di perkotaan sebesar $1 \%$ akan mempengaruhi penurunan $\mathrm{P} 0, \mathrm{P} 1$, dan $\mathrm{P} 2$ masing-masing sebesar 0,25\%; 1,57\%; dan $2,23 \%$. Penurunan kemiskinan yang tinggi di pedesaan daripada di perkotaan sebagai dampak peningkatan pendapatan menunjukkan banyaknya penduduk miskin di pedesaan. Proporsi P0, P1, dan P2 di pedesaan berturut-turut sebesar 0,87; 0,89 dan 0,86 lebih tinggi dari perkotaan berturut-turut sebesar 0,13 ; 0,12 , dan 0,12 .

Tabel 8 menunjukkan dekomposisi perubahan indeks kemiskinan menurut berbagai tipe dampak. Perubahan indeks kemiskinan adalah persentase perubahan indeks kemiskinan sebagai akibat perubahan pendapatan perkapita karena terjadi peningkatan output perkapita sebesar Rp. 1 juta yang dihasilkan dalam proses produksi. 
Tabel 8 Perubahan indeks kemiskinan (P0, P1, dan P2) menurut tipe dampak*)

\begin{tabular}{|c|c|c|c|c|c|c|c|c|c|}
\hline \multirow{2}{*}{$\begin{array}{c}\text { Indeks } \\
\text { kemiskinan/Tipe } \\
\text { dampak } \\
\end{array}$} & \multicolumn{9}{|c|}{ Sektor ekonomi } \\
\hline & 1 & 2 & 3 & 4 & 5 & 6 & 7 & 8 & 9 \\
\hline \multicolumn{10}{|l|}{ P0 } \\
\hline Langsung & $-0,0019$ & $-0,0012$ & $-0,0016$ & $-0,0007$ & $-0,0028$ & $-0,0025$ & $-0,0007$ & $-0,0100$ & $-0,0005$ \\
\hline Tidak langsung & $-0,0012$ & $-0,0027$ & $-0,0010$ & $-0,0010$ & $-0,0023$ & $-0,0028$ & $-0,0007$ & $-0,0021$ & $-0,0007$ \\
\hline Induksi konsumsi & $-0,0147$ & $-0,0123$ & $-0,0138$ & $-0,0063$ & $-0,0105$ & $-0,0111$ & $-0,0128$ & $-0,0113$ & $-0,0058$ \\
\hline Total & $-0,0378$ & $-0,0239$ & $-0,0371$ & $-0,0141$ & $-0,0200$ & $-0,0218$ & $-0,0348$ & $-0,0234$ & $-0,0097$ \\
\hline \multicolumn{10}{|l|}{ P1 } \\
\hline Langsung & $-0,0116$ & $-0,0070$ & $-0,0094$ & $-0,0044$ & $-0,0167$ & $-0,0150$ & $-0,0039$ & $-0,0597$ & $-0,0030$ \\
\hline Tidak langsung & $-0,0071$ & $-0,0161$ & $-0,0058$ & $-0,0058$ & $-0,0139$ & $-0,0169$ & $-0,0041$ & $-0,0124$ & $-0,0040$ \\
\hline Induksi konsumsi & $-0,0880$ & $-0,0738$ & $-0,0823$ & $-0,0379$ & $-0,0629$ & $-0,0661$ & $-0,0767$ & $-0,0673$ & $-0,0348$ \\
\hline Total & $-0,2260$ & $-0,1426$ & $-0,2219$ & $-0,0840$ & $-0,1193$ & $-0,1303$ & $-0,2081$ & $-0,1396$ & $-0,0580$ \\
\hline \multicolumn{10}{|l|}{$\mathbf{P 2}$} \\
\hline Langsung & $-0,0164$ & $-0,0098$ & $-0,0132$ & $-0,0062$ & $-0,0235$ & $-0,0212$ & $-0,0055$ & $-0,0840$ & $-0,0042$ \\
\hline Tidak langsung & $-0,0100$ & $-0,0227$ & $-0,0082$ & $-0,0082$ & $-0,0196$ & $-0,0238$ & $-0,0057$ & $-0,0175$ & $-0,0056$ \\
\hline Induksi konsumsi & $-0,1240$ & $-0,1039$ & $-0,1159$ & $-0,0533$ & $-0,0886$ & $-0,0932$ & $-0,1080$ & $-0,0948$ & $-0,0491$ \\
\hline Total & $-0,3183$ & $-0,2009$ & $-0,3124$ & $-0,1184$ & $-0,1681$ & $-0,1836$ & $-0,2930$ & $-0,1967$ & $-0,0818$ \\
\hline \multicolumn{10}{|l|}{ P0 } \\
\hline Langsung & $-0,0014$ & $-0,0006$ & $-0,0051$ & $-0,0013$ & $-0,0003$ & $-0,0005$ & $-0,0012$ & $-0,0024$ & $-0,0008$ \\
\hline Tidak langsung & $-0,0019$ & $-0,0011$ & $-0,0035$ & $-0,0033$ & $-0,0002$ & $-0,0004$ & $-0,0016$ & $-0,0019$ & $-0,0011$ \\
\hline Induksi konsumsi & $-0,0133$ & $-0,0088$ & $-0,0108$ & $-0,0111$ & $-0,0075$ & $-0,0070$ & $-0,0081$ & $-0,0132$ & $-0,0139$ \\
\hline Total & $-0,0222$ & $-0,0152$ & $-0,0168$ & $-0,0164$ & $-0,0094$ & $-0,0094$ & $-0,0135$ & $-0,0200$ & $-0,0221$ \\
\hline \multicolumn{10}{|l|}{ P1 } \\
\hline Langsung & $-0,0081$ & $-0,0036$ & $-0,0302$ & $-0,0077$ & $-0,0016$ & $-0,0028$ & $-0,0071$ & $-0,0143$ & $-0,0048$ \\
\hline Tidak langsung & $-0,0112$ & $-0,0068$ & $-0,0207$ & $-0,0200$ & $-0,0012$ & $-0,0025$ & $-0,0095$ & $-0,0113$ & $-0,0068$ \\
\hline Induksi konsumsi & $-0,0793$ & $-0,0525$ & $-0,0644$ & $-0,0665$ & $-0,0446$ & $-0,0419$ & $-0,0485$ & $-0,0787$ & $-0,0832$ \\
\hline Total & $-0,1322$ & $-0,0904$ & $-0,1001$ & $-0,0977$ & $-0,0554$ & $-0,0558$ & $-0,0804$ & $-0,1188$ & $-0,1314$ \\
\hline \multicolumn{10}{|l|}{$\mathbf{P 2}$} \\
\hline Langsung & $-0,0114$ & $-0,0051$ & $-0,0426$ & $-0,0108$ & $-0,0023$ & $-0,0039$ & $-0,0101$ & $-0,0201$ & $-0,0068$ \\
\hline Tidak langsung & $-0,0158$ & $-0,0095$ & $-0,0291$ & $-0,0282$ & $-0,0018$ & $-0,0035$ & $-0,0133$ & $-0,0159$ & $-0,0096$ \\
\hline Induksi konsumsi & $-0,1117$ & $-0,0740$ & $-0,0907$ & $-0,0936$ & $-0,0628$ & $-0,0591$ & $-0,0683$ & $-0,1109$ & $-0,1173$ \\
\hline Total & $-0,1864$ & $-0,1274$ & $-0,1411$ & $-0,1377$ & $-0,0782$ & $-0,0787$ & $-0,1134$ & $-0,1675$ & $-0,1853$ \\
\hline
\end{tabular}

*) persentase perubahan $\mathrm{P} \alpha$ sebagai akibat perubahan output perkapita sebesar Rp. 1 juta

Keterangan:
1. Pertanian padi dan palawija
2. Hortikultura
3. Perkebunan
4. Perikanan
5. Peternakan
6. Kehutanan
7. Pertambangan dan penggalian
8. Industri pengolahan
9. Listrik, gas, dan air

Pada tabel diatas terlihat bahwa pengaruh perubahan output masingmasing sektor ekonomi menimbulkan dampak yang berbeda-beda terhadap
10. Konstruksi

11. Perdagangan

12. Hotel dan rumah makan

13. Transportasi dan pergudangan

14. Informasi dan komunikasi

15. Keuangan, asuransi dan jasa perusahaan

16. Jasa pendidikan

17. Jasa kesehatan

18. Jasa pemerintahan dan perorangan

penurunan kemiskinan. Dampak aktifitas produksi yang dianalisis dalam peneitian ini terdiri dari dampak langsung, tidak langsung, induksi konsumsi, dan total. 
Dampak total penurunan kemiskinan tergantung pada struktur produksi, dukungan industri, dan pola konsumsi penduduk. Sektor ekonomi yang mempunyai keterkaitan tinggi dengan sektor ekonomi lainnya dalam proses produksi, selain memberikan dampak yang tinggi terhadap tota output juga akan memberikan dampak terhadap penurunan kemiskinan yang tinggi jika sektor ekonomi tersebut memberikan peningkatan pendapatan pada penduduk miskin. Dampak langsung yang tinggi pada penurunan $\mathrm{P} 0, \mathrm{P} 1$ dan $\mathrm{P} 2$ terjadi pada sektor sektor industri yang menunjukkan sektor tersebut cenderung menggunakan banyak tenaga kerja (padat karya) dalam proses produksinya. Selain itu sektor industri di Kalimantan Barat dalam proses produksinya melibatkan sektor lain seperti pertanian sebagai sumber bahan baku sehingga memberikan pendapatan bagi banyak penduduk miskin pada sektor pertanian. Dampak langsung peningkatan output perkapita sektor industri sebesar Rp 1 juta mempengaruhi penurunan $\mathrm{P} 0, \mathrm{P} 1$, dan P2 masing-masing sebsar 0,0100\%; $0,0597 \%$ dan $0,0840 \%$. Pengembangan sektor industri dapat memberikan dampak yang tinggi terhadap penurunan kemiskinan jika industri yang dikembangkan berbasis pertanian (argoindustri).

Penurunan kemiskinan (P0) sebagai dampak total aktifitas produksi pada sektor pertanian dan pertambangan tertinggi diantara sektor lain yaitu antara $0,0141 \%$ hingga $0,0378 \%$. Sedangkan penurunan kemiskinan (P0) pada sektor industri sebesar $0,0234 \%$ dan sektor perdagangan dan jasa-jasa antara $0,0094 \%$ hingga $0,0222 \%$. Sektor konstruksi merupakan sektor dengan penurunan kemiskinan tertinggi pada sektor jasa-jasa yaitu sebesar 0,0222\%. Sektor pertanian padi dan palawija, perkebunan, dan pertambangan merupakan sektor ekonomi dengan penurunan kemiskinan (P0) tertinggi berturut-turut $0,0378 \% ; 0,0371 \%$, dan $0,0348 \%$. Penurunan kemiskinan yang cukup tinggi pada sektor-sektor pertanian yaitu pertanian padi dan palawija dan perkebunan, sudah sewajarnya terjadi, sejalan dengan masih banyaknya penduduk miskin yang menggantungkan hidupnya dan memperoleh pendapatan melalui lapangan usaha sektor pertanian. Manfaat peningkatan output yang terjadi pada sektor pertanian akan banyak dinikmati oleh kelompok rumah tangga miskin dengan adanya peningkatan pendapatan.

\section{KESIMPULAN}

Keterkaitan antar sektor ekonomi dengan penurunan kemiskinan penting dalam kajian kebijakan pengentasan kemiskinan. Ketika pengentasan kemiskinan melalui bantuan sosial mengalami keterbatasan dalam anggaran, kebijakan pengembangan sektor ekonomi menjadi kebijakan yang tepat untuk mengurangi jumlah penduduk miskin secara berkelanjutan. Penelitian ini bertujuan untuk mengkaji peranan sektor ekonomi dalam pembentukan output, penyerapan tenaga kerja, distribusi pendapatan, serta usaha dalam pengentasan kemiskinan. Dekomposisi pengentasan kemiskinan digunakan untuk menunjukkan pengaruh pertumbuhan output terhadap penurunan kemiskinan sebagai dasar pengambilan kebijakan pengentasan kemiskinan di Kalimantan Barat. Sektor pertanian masih mempunyai peran penting dalam perekonomian di Kalimantan Barat. Hal ini ditujukkan oleh tingginya peran pertanian khususnya pertanian padi dan palawija dalam pembentukan output, penyerapan tenaga kerja, dan distribusi pendapatan rumah tangga. 
Dampak perubahan permintaan akhir output sektor ekonomi terhadap penurunan kemiskinan tergantung pada peningkatan pendapatan yang didistribusikan kepada rumah tangga miskin. Peningkatan pendapatan rumah tangga dalam perekonomian ditunjukkan oleh pengganda pendapatan (income multiplier) sebagai akibat perubahan permintaan akhir output sektor ekonomi. Peranan peningkatan pendapatan terhadap pengentasan kemiskinan tergantung dari elastisitas kemiskinan dan tingkat pendapatan pada kelompok rumah tangga yang diperoleh dari proses produksi. Pengentasan kemiskinan dianalisis dengan menggunakan indeks kemiskinan FGT menurut tipe dampak langsung, tidak langsung, induksi konsumsi, dan total dalam I-O Miyazawa. Dampak langsung penurunan kemiskinan tertinggi terjadi pada sektor industri sedangkan dampak total tertinggi terjadi pada sektor pertanian tanaman padi dan palawija.

Pengembangan sektor industri menjadi kebijakan yang harus dilakukan. Sektor industri mempunyai peranan dalam meningkatkan perekonomian dan pengentasan kemiskinan. Sektor industri yang akan dikembangkan tergantung pada jenis industri dan teknologi yang akan digunakan. Industri berbasis pertanian (agroindustri) dengan banyak tenaga kerja (padat karya) akan memberikan manfaat terhadap peningkatan perekonomian dan pengentasan kemiskinan. Pengembangan industri akan berdampak pada penyerapan tenaga kerja dan mobilisasi tenaga kerja dari sektor lain. Tenaga kerja sebagai faktor produksi pada sektor industri harus dibekali dengan pendidikan dan pelatihan sehingga terjadi peningkatan pendapatan sebagai balas jasa faktor produksi.

\section{DAFTAR PUSTAKA}

Ames B, Brown W, Devarajan S, Izquierdo A. 2001 .

Macroeconomic Policy and Poverty Reduction. New York (US): IMF-World Bank.

$\begin{array}{lllr}\text { Arsyad L. } & \text { 2010. } & \text { Ekonomi } \\ \text { Pembangunan. } & \text { Ed } & \text { ke-5. } \\ \text { Yogyakarta } & \text { (ID): } & \text { UPP } & \text { STIM } \\ \text { YKPM. } & & & \end{array}$

[BPS] Badan Pusat Statistik. 2000. Kerangka Teori dan Analisis Tabel Input Output. Jakarta (ID): Badan Pusat Statistik. 2013. Berita Resmi Statistik No.39/07/61 Th. XVI. Pontianak (ID): Badan Pusat Statistik.

2013b. Produk Domestik Regional Bruto Menurut Lapangan Usaha Provinsi Kalimantan Barat. Pontianak (ID): Badan Pusat Statistik.

Bourguignon F. 2004. The PovertyGrowth-Inequality Triangle.

Washington (US):World Bank.

Daryanto A, Hafizrianda Y. 2010. Analisis Input-Output dan Social Accounting Matrix untuk Pembangunan Ekonomi Daerah. Bogor (ID): IPB Press.

Datt G, Ravallion M. 1996. How Important to India's Poor is the Sectoral Composition of Economic Growth?: The World Bank Economic Review. 10(1):1-25.

Dewbre J, Godoy DC, Sorescu S. 2011. Agricultural Progress and Poverty Reduction: OECD Food, Agriculture and Fisheries Working Papers. Paris (FR):OECD Publishing.

Foster JE, Greer J, Thorbecke E. 1984. A Class of Decomposable Poverty Measures: Econometrica. (52):761-766. 
Jensen RC, West GR. 1986. InputOutputfor Practioners: Theory and Applications. Canberra (AU): Aurtralian Government Publishing Service.

Kakwani N, Khandker S, Son HH. 2004. Pro-poor growth: concepts and measurement with country case studies. Brazil: UNDP Working Paper. (1).

Leontief W. 1986. Input-Output Economics. Second Edition. Oxford (UK): Oxford University Press.

Lipton M, Ravallion M. 1993. Poverty and Policy. New York (US): World Bank.

Matsuyama K. 1992. Agricultural Productivity, Comparative Advantage, and Economic Growth: Journal of Economic Theory. 58:17-34.

Miyazawa K. 1968. Input-Output analysis and intrrelational income multiplier as a matrix: Hitotsubashi Journal of Economics. (8)2:39-58.

Nasoetion, LI. 1993. Identifikasi masalah dan Pendekatan Pengentasan Kemiskinan: Suatu Restrospeksi. LPM-IPB.

Nazara S. 2005. Analisis Input Output. Edisi ke 2. Jakarta (ID): Lembaga Penerbit Fakultas Ekonomi Universitas Indonesia.
Pasaribu, B. 2006. Poverty Profile and the Alleviation Programs in Indonesia. Paper presented in Asian Regional Seminar on Poverty Allevation, held by AFPPD and IFAD, 5-6 April 2006, Hanoi, Vietnam.

Ravallion M, Datt G. 2002. Why has Economic Growth been More ProPoor in Some States of India Than Others: Journal of Development Economics. 68:381-400.

Sajogyo. 2002. Pertanian dan Kemiskinan: Jurnal Ekonomi Rakyat. 1(1):1-15

Sudaryanto T, Rusastra IW. 2006. Kebijakan Strategis Usaha Pertanian dalam Rangka Peningkatan Produksi dan Pengentasan Kemiskinan: Jurnal Litbang Pertanian. 25(4):115-122

Thorbecke, E. Jung HS. 1994. A multiplier decomposition method to analyze poverty alleviation: Journal of Development Economics. (48)1:279-300.

Yudhoyono, SB. 2004. Pembangunan Pertanian dan Perdesaan Sebagai Upaya Mengatasi Kemiskinan dan Pengangguran: Analisis EkonomiPolitik Kebijakan Fiskal [Desertasi]. IEP-IPB. Bogor. 